\title{
Development of Appropriate Water Treatment Packages in Mongolia
}

\author{
Young Kyu Park, Ju-Suk An, Ji Young Kim, Chan Kyu Park, Hyun Je Oh, and Jae-Roh Park
}

\begin{abstract}
This study investigated to choose the water treatment process prototype after carrying a field survey to construct $\mathrm{E}^{3}$ Water System in Mongolia which was chosen among the major target countries, selecting water quality evaluation standards, and drawing up elementary technologies applicable to the local areas. The process plan for was applied in Mongolia to catch water from underground water as the major source of water supply and the riverside filtered water which has better water quality. In addition, it was considered that the concentration of manganese and bacteria was detected more than our domestic standards or their standards through water quality analysis in Mongolia. In Mongolia, there was a problem that we should consider the pollutants in the water source due to climate change and industrial development. It is necessary to package and standardize each water treatment process suitable for water quality conditions and processing objectives for each region.
\end{abstract}

Index Terms-Manganese, bacteria, mongolia, water treatment process.

\section{INTRODUCTION}

\section{A. Purpose of Study}

There have been international recognition and efforts to improve the water service and distribution of basic sanitation systems. A leading example is adoption of 'UN Millennium Declaration' by all 189 member nations in attendance of 147 heads of state at the 55th UN General Meeting on September 8, 2000. Following the declaration, the Millennium Development Goals (MDGs) which included the plan to reduce the population not supplied of clean drinking water and without the basic sanitation system to half was established. To achieve the goal of supplying the clean water service to 260,000 people and providing the basic sanitation system to 370,000 people, an investment of KRW 14 trillion to 16 trillion annually is needed in addition to existing investment (Korea Institute for International Trade, 2010). In that aspect, a strategic approach to actively participate in international assistance of developing countries is needed.

\section{B. Scope of Study}

Korea Institute of Construction Technology (KICT) intends to develop the policy/technology cooperative

Manuscript received April 15, 2014; revised June 18, 2014.

Young Kyu Park, Ju-Suk An, Ji Young Kim, Hyun Je Oh, and Jae-Roh Park are with Korea Institute of Construction Technology (KICT), 283, Goyangdae-Ro, Ilsanseo-Gu, Goyang-Si, Gyeonggi-Do, 411-712, Korea (e-mail: ykpark@kict.re.kr, jusuk@kict.re.kr, jyk@kict.re.kr, hjoh@kict.re.kr, jrpark@kict.re.kr).

Chan Kyu Park is with Korea Testing Laboratory (KTL), 7, Gurodigital 8-gil, Guro-gu-Gu, Seoul, 152-718, Korea (e-mail: parkcg@ktl.re.kr). network related to water industry (water service) of developing countries and conduct the joint research project to develop the water treatment package customized for developing countries. It is part of 'Multipurpose (underdeveloped countries, emergency management and distributed) small scale water treatment package development' program. Its objective is to use the outcome of the research project to lead the water industry market in developing countries and develop the overseas business network as well as to distribute and proliferate Korea's cutting-edge water service technology to developing countries to solidify Korea's position as the environmentally advanced country in the international community.

To promote the water industry in the global markets, the regional specific strategy of segmenting the world's water markets according to the economic condition and potential for adopting the advanced technology and then developing the package combining the region, emerging area and core technology is needed.

Fig. 1 shows $\mathrm{E}^{3}$ Water System as the water treatment system optimized to local environmental changes of developing countries mostly in the Asian region which is considered as the key export market of Korea's environmental technology.

This study selected Mongolia as a target for its extreme conditions and selected the criteria for site survey and water quality evaluation then deduced the applicable element technology for the region to select the water treatment process for the $\mathrm{E}^{3}$ Water System.

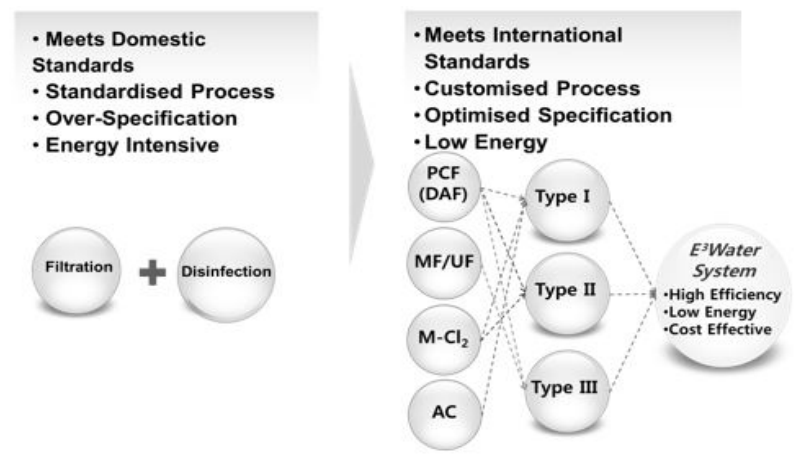

Fig. 1. $\mathrm{E}^{3}$ Water system.

\section{PRocess SElection}

\section{A. Water Resource Status in Mongolia}

Mongolia is an inland country with very low rain fall of $350 \mathrm{~mm}$ in average annually but has a relatively rich water resource. There are around 3,800 streams and rivers, around 3,500 lakes and 186 glaciers. Total surface water flux is 
$599 \mathrm{~km} 3$, and more than $90 \%$ of it consists of lakes $(500 \mathrm{~km} 3)$ and glaciers (62.9km3).

In Mongolia, lakes occupy most of its resources at $82 \%$. Rivers and streams occupy $34.6 \mathrm{~km} 3,6 \%$ of total water resources in the country. The underground water flux is $10.8 \mathrm{~km} 3$, only $2 \%$ of total (Fig. 2). More than $78 \%$ of water resources are located in the mountainous areas of northern, western and northeastern regions, which occupy $36 \%$ of total land, while the remaining is located in the southern region. Although the portion of underground water in total water resources is not high, the actually utilized water resources constitute of $20 \%$ surface water and $80 \%$ underground water because of water quality and ease of access. The underground water is the most important water source for households, livestock and industrial use (Fig. 3) [1]-[3].

The water supply status differs greatly according to the region as the clean water to be used for drinking or farming is limited. In rural areas, $30 \%$ of drinking water is supplied by the centralized waterworks while $70 \%$ is supplied by the portable systems, wells, and streams (Fig. 4) [4].

The drinking water system in Mongolia uses the centralized waterworks constructed in 1958, and some pipes are in very poor condition as they are used for over 40 years. Moreover, development of new supply source is needed as the existing drinking water system cannot cope with increasing demands for water.

In the urban areas of Mongolian capital Ulaanbataar, the underground water is disinfected by chlorine, but it is used without the treatment in the suburban areas. Most of drinking water depends on the underground water, and the bacteria, nitrogen, iron, manganese, fluorine, and or arsenic are detected in some areas.

As the environmental problem due to the rapid modernization has become a social issue, Mongolia needs the water treatment technology and environmental management suitable for the local water quality status.

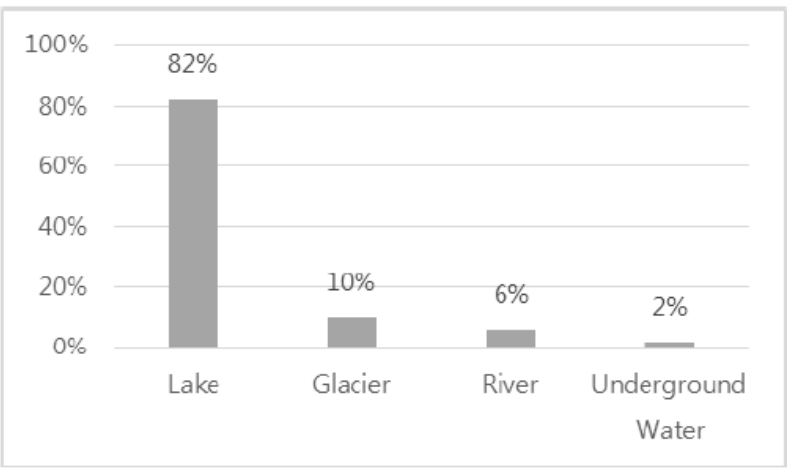

Fig. 2. Status of the water resources in Mongolia.

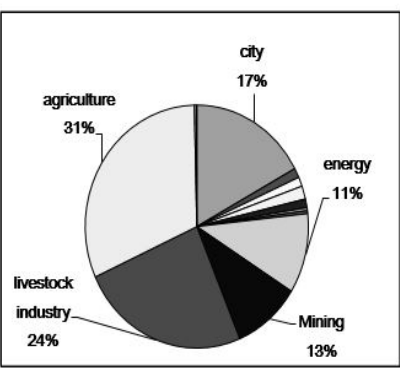

324.5 million tons [2008]

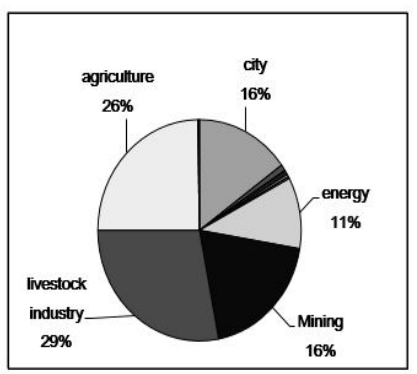

324.2 million tons [2010]
Fig. 3. Groundwater usage in Mongolia.

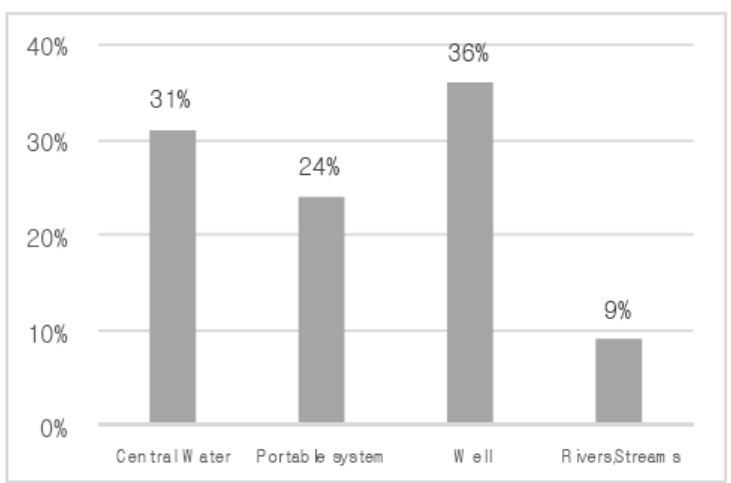

Fig. 4. Drinking water supply sector in mongolia.

\section{B. Experimental Methods}

Fig. 5 shows experimental methods for $\mathrm{E}^{3}$ Water System.

Field investigations of test-bed sites are conducted to examine the regional characteristics and local pollutants. It is the most important element of technical application in developing countries. Most of localized technology development failed because field investigations were not conducted properly. Since the viewpoints of standard, criteria, and technology are all different, the development must be based on the data through field investigations. It is also for putting to practical use.

Once the local conditions are identified, water quality is evaluated by in-depth laboratory analyses. Water quality standards are set to meet the international standards both for drinking and domestic water supply.

Then, the most appropriate water treatment technology is chosen for each test-bed sites, with consideration of technology's current applicability as well as future development. Instead of the single dimensional and one-shot technology, sustainable process is needed.

Development of the self-reliant or supportable maintenance technology and manual and training for local personal is very important for proper maintenance and operation

By doing this, the standardized and over-specified water treatment processes are replaced by optimally specified processes customized for local needs and conditions. For better commercialization, the customized water treatment system achieves high efficiency, low energy and cost effectiveness, creating an $E^{3}$ water system. The $E^{3}$ water system will use locally available resources and provide customized operating manual for sustainable operation and maintenance.

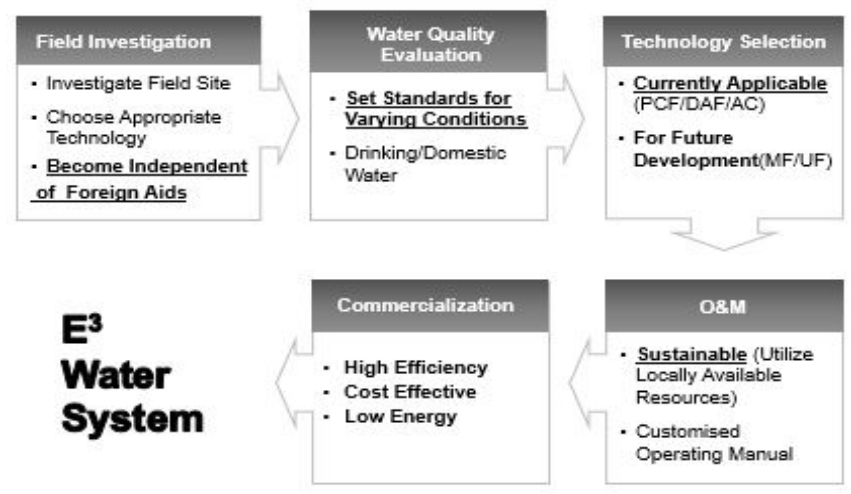

Fig. 5. Experimental methods for $E^{3}$ water system. 


\section{Applicable Technology Selection}

Mongolian Water Authority is preparing a project and legislation to develop the water service infrastructure. For that, it requested the technical support and pilot project in Mongolia to Korean Government. This research project was kicked off with field investigations in 2011 and executed in details. The water treatment package for Mongolia was installed in 2013 and is currently in operation.

TABLE I: THE ANALYSIS OF THE RAW WATER (GROUNDWATER)

\begin{tabular}{|c|c|c|c|c|}
\hline No & Test items & Standard & Result & Decision \\
\hline 1 & 1,1,1-Trichloroethane(mg/L) & Below 0.1 & $\begin{array}{c}\text { Not } \\
\text { detected }\end{array}$ & Suitability \\
\hline 2 & 1,1-Dichloroethylene(mg/L) & Below0.03 & $\begin{array}{c}\text { Not } \\
\text { detected }\end{array}$ & Suitability \\
\hline 3 & $\begin{array}{c}\text { 1,2-Dibromo-3-Chloropropane } \\
\text { (mg/L) }\end{array}$ & $\begin{array}{c}\text { Below } \\
0.001\end{array}$ & $\begin{array}{c}\text { Not } \\
\text { detected }\end{array}$ & Suitability \\
\hline 4 & 1,4-Dioxane(mg/L) & Below 0.05 & $\begin{array}{c}\text { Not } \\
\text { detected }\end{array}$ & Suitability \\
\hline 5 & Hardness(mg/L) & Below 300 & 92 & Suitability \\
\hline 6 & $\begin{array}{l}\text { Consumption of potassium } \\
\text { permanganate }(\mathrm{mg} / \mathrm{L})\end{array}$ & Below 10 & 3.2 & Suitability \\
\hline$\cdots$ & $\cdots$ & $\cdots$ & $\cdots$ & $\cdots$ \\
\hline 13 & Manganese(mg/L) & $\begin{array}{c}\text { Below } \\
0.3(0.1)\end{array}$ & 0.454 & $\begin{array}{c}\text { Incongruit } \\
\mathrm{y}\end{array}$ \\
\hline 14 & Benzene(mg/L) & Below 0.01 & $\begin{array}{c}\text { Not } \\
\text { detected }\end{array}$ & Suitability \\
\hline 15 & Fecal coliform(/100mL) & $\begin{array}{c}\text { Not } \\
\text { detected }\end{array}$ & $\begin{array}{c}\text { Not } \\
\text { detected }\end{array}$ & Suitability \\
\hline 16 & Total colony counts(CFU/mL) & Below 100 & 230 & $\begin{array}{c}\text { Incongruit } \\
\mathrm{y}\end{array}$ \\
\hline & & & & \\
\hline
\end{tabular}

At first, field investigations of test-bed sites were conducted to examine the regional characteristics and local pollutants. Table I is the analysis of the raw water at the test bed site in 2011. The major water source is groundwater, but it is found to have excess manganese and bacteria. This area near the test-bed site receives $100 \%$ of drinking water through the well, stream, truck, kiosk due to the lack of water service infrastructure. There are around 1,000 households concentrated near the area. Assuming 4 persons per family, around 4,000 people are potential water consumers. The residential types are $100 \%$ gers and standalone houses. There is no apartment building. In the area, the water is consumed at a rate of $6 \sim 8 \mathrm{~L}$ /person/day which is far lower than 240 350 $\mathrm{L} /$ person/day in the apartment complexes. And the drinking water is polluted to heavy metals, etc. The population for the water supply service is around 2,500 people and the treatment capacity is $24 \mathrm{~m}^{3} / \mathrm{day}$. Table II shows about the details of the water treatment package.

The water treatment package was produced in a one-skid format within an ISO specification $20 \mathrm{ft}$ container in which the equipment can be disassembled (Fig. 6). The container and equipment is built as one body for movement. It was modified into a cold-resistant container considering the operation situation in extreme climates. The main process was made for removal of manganese with the two process methods of 'pre-chlorination + sand filtration' and 'manganese-coated sand filtration'. It was built for UV disinfection to remove bacteria [5].

TABLE II: DETAILS OF THE WATER TREATMENT PACKAGE

\begin{tabular}{|c|c|}
\hline Treated materials & \multicolumn{1}{|c|}{ Manganese and bacteria } \\
\hline Application target & \multicolumn{1}{c|}{ Groundwater } \\
\hline Dimension & $\begin{array}{l}\text { The components in the ISO 20ft container can be } \\
\text { disassembled in one skid form. The container and } \\
\text { equipment can be transported in a single body. In } \\
\text { Equipment type } \\
\text { container is insulated. }\end{array}$ \\
\hline Treatment capacity & \multicolumn{1}{c|}{ 24 $\mathrm{m}^{3} /$ day } \\
\hline Main Processes & $\begin{array}{l}\text { Pre-chlorination, Sand filter, Manganese-coated } \\
\text { Sand filter, UV(Ultra-Violet) }\end{array}$ \\
\hline Site & \multicolumn{2}{c}{ Ulaanbattar } \\
\hline
\end{tabular}

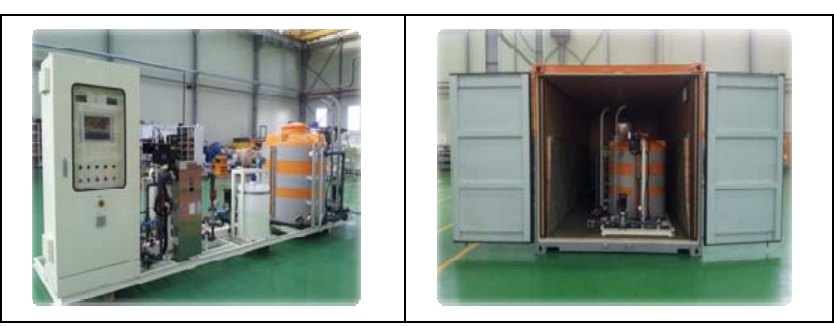

Fig. 6. Small water treatment package for towns in mongolia (one skid type with ISO 20 feet container).

\section{RESUlTS AND DISCUSSION}

The efficiency of the system in removing manganese was evaluated by assuming raw water in Mongolia contains high concentration of manganese. The water containing manganese with estimated concentration of $10 \mathrm{mg} / \mathrm{L}$ or higher is produced, and the concentration change after the process is compared using manganese acetate. The removal efficiency is evaluated through the tests before and after the treatment under the conditions of operating modes 1 and 2 (see Table III).

TABLE III: THE CONDITIONS OF OPERATING MODES

\begin{tabular}{|c|c|}
\hline Mode & Treatment Processes \\
\hline 1 & Pre-chlorination + Sand filter + UV(Ultra-Violet) \\
\hline 2 & Manganese-coated Sand filter + UV(Ultra-Violet) \\
\hline
\end{tabular}

The Test 1 was the control group of test 2 and test 3 . It was tested at the operating mode 1 . The water was passed through the sand filtering without pre-chlorine. The manganese concentration was 10.5 ppm initially and then 9.3 ppm after the filtering. Test 2 was conducted at the operating mode 2. The pre-chlorination was uniformly supplied so that the residual chlorine concentration was maintained at $0.8 \mathrm{mg} / \mathrm{L}$ or higher [6]. It was confirmed that the sand filter was coated with manganese and turned black. The manganese removal efficiency was high as the manganese concentration was 10.1 ppm initially and then $0.01 \mathrm{ppm}$ after the treatment. Test 3 was conducted at the operating mode 2 . The water passed 
through the manganese-coated sand filter without the pre-chlorine. The manganese concentration changed from $10.3 \mathrm{ppm}$ initially to $0.012 \mathrm{ppm}$ after the treatment as shown in Fig. 7.

Test 1 was the control group. Despite a prolonged operation, it showed low treatment efficiency. It shows that the manganese is not removed without the specific treatment. Test 2 and 3 showed more than 99\% treatment efficiency. It is expected that the efficiency would be $99 \%$ or higher if the operation was extended. Potable water for meeting the water quality standard of less than manganese of $0.1 \mathrm{mg} / \mathrm{L}$ can be produced from raw water in Mongolia.

The process using UV was selected for post-treatment and disinfection. Total colony counts of $200 \mathrm{CFU} / \mathrm{mL}$ from raw water were removed completely by UV.

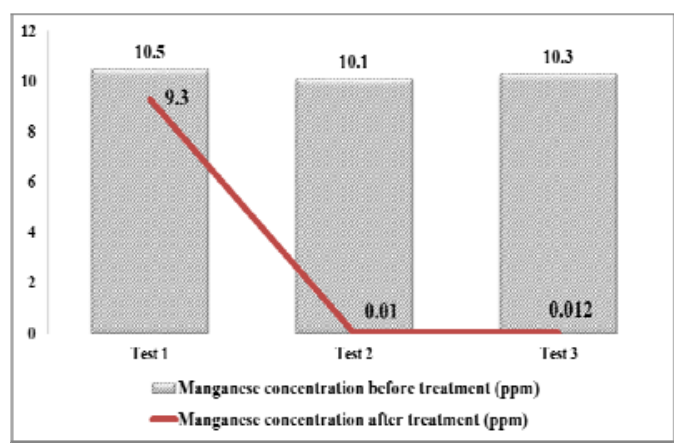

Fig. 7. Manganese concentration before and after treatment by each test.

TABLE IV: The ANALYZING DATA OF MAJOR POLLUTANTS

\begin{tabular}{|c|c|c|c|c|}
\hline Target Item & \multicolumn{2}{|c|}{$\begin{array}{c}\text { Manganese } \\
\text { (mg/L) }\end{array}$} & \multicolumn{2}{c|}{$\begin{array}{c}\text { Total Colony Counts } \\
\text { (CFU/mL) }\end{array}$} \\
\hline $\begin{array}{c}\text { Water quality } \\
\text { Standard }\end{array}$ & \multicolumn{2}{|c|}{ Below 0.3(0.1) } & \multicolumn{2}{c|}{ Below 100 } \\
\hline \hline $\begin{array}{c}\text { Date } \\
\text { (month/year) }\end{array}$ & $\begin{array}{c}\text { Raw } \\
\text { Water }\end{array}$ & $\begin{array}{c}\text { Product } \\
\text { Water }\end{array}$ & $\begin{array}{c}\text { Raw } \\
\text { Water }\end{array}$ & $\begin{array}{c}\text { Product } \\
\text { Water }\end{array}$ \\
\hline '09/2012 & 1.54 & $\begin{array}{c}\text { Not } \\
\text { detected }\end{array}$ & 210 & $\begin{array}{c}\text { Not } \\
\text { detected }\end{array}$ \\
\hline '10/2012 & 1.24 & 0.01 & 208 & $\begin{array}{c}\text { Not } \\
\text { detected }\end{array}$ \\
\hline '11/2012 & 1.02 & 0.02 & 230 & $\begin{array}{c}\text { Not } \\
\text { detected }\end{array}$ \\
\hline '12/2012 & 1.62 & $\begin{array}{c}\text { Not } \\
\text { detected }\end{array}$ & 225 & $\begin{array}{c}\text { Not } \\
\text { detected }\end{array}$ \\
\hline '01/2013 & 1.42 & 0.009 & 205 & $\begin{array}{c}\text { Not } \\
\text { detected }\end{array}$ \\
\hline '02/2013 & 1.15 & $\begin{array}{c}\text { Not } \\
\text { detected }\end{array}$ & 202 & $\begin{array}{c}\text { Not } \\
\text { detected }\end{array}$ \\
\hline
\end{tabular}

The quality of the raw water and product water is inspected to check the performance and operating condition of the water treatment package. The water quality is analyzed using the local water quality testing agency in Mongolia and Korea. The water treatment package is operated for around 20 days each month. As of February 2014, around $602.9 \mathrm{~m}^{3}$ treated water has been produced. Table IV is the analyzing data of the raw water and the product water about major pollutants by using the water treatment package for six months. Manganese, and bacteria which were the problems in the area where the water treatment package was installed in Mongolia, were removed to be below the water quality standard during the operation period.

\section{CONCLUSION}

Investigations of various regional conditions and water quality analyses led to development of customized small-scale water treatment system. The major water source in Mongolia is groundwater, but it was found to have excess manganese and bacteria. Pre-chlorination and sand filter was selected to treat manganese. It was found that the water quality conditions and standards differ in different countries, while climate change and industrialization are constantly impacting the water environment detrimentally. Therefore, careful selection and customization of treatment processes is imperative. Considering the potential development of resource rich Mongolia, the desire to improve quality of life in relation to rapidly developing social infrastructure. As the recognition of clean drinking water changes, it is expected that the mutual cooperation based on partnership with the Mongolian agencies will create many demands for development of environmental infrastructure in Mongolia. Successful expansion of water treatment technology into the global market requires appropriate customization that meets the local conditions and needs. It is necessary to select appropriate technologies that can be localized and it is also necessary to apply sustainable process technologies rather than single-dimensional one-time application technologies. Also, renewable energy and locally available resources need to be utilized for more sustainable development, operation, and maintenance.

\section{ACKNOWLEDGMENTS}

This research was supported by Korea Ministry of Environment as "The Eco-Innovation Project (Global Top Project)”. (GT-SWS-11-01-008-0)

This research was supported by a grant from a Strategic Research Project (20140030-1-1) funded by Korea Institute of Construction Technology.

\section{REFERENCES}

[1] N. Jadambaa, “Ground water of mongolia,” White Book of Mongolia, Ulaanbaatar, pp. 199-214, 2002.

[2] P. Abatima and D. D. Agvadorj, Climate Change and Its Impacts in Mongolia, National Agency for Meteorology, Hydrology and Environmental Monitoring and JEMR Publishing, Ulaanbaatar, Mongolia, p. 2007, 2000.

[3] D. B. Myagmarjav and G. Davaa, Surface Water of Mongolia, Interpress, Ulaanbaatar, p. 345, 1999.

[4] UNEP RRC. AP, Mongolia: State of the Environment, p. 22, 2002.

[5] J. K. Kim, S. G. Jeong, J. S. Kim, and S. J. Park, “Manganese removal in water treatment processes," Journal of the Korean Society of Water and Wastewater, vol. 19, no. 5, pp. 595-604, 2005.

[6] B. S. Kim, J. K. Kim, H. W. Ann, and C. H. Kim, "Effect of experimental factors on manganese removal in manganese sand filtration," Journal of the Korean Society of Water and Wastewater, vol. 20, no. 1, pp. 86-93, 2006.

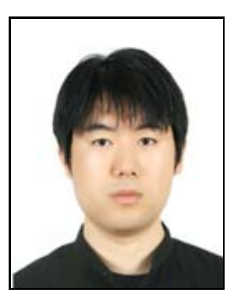

Young Kyu Park was born on August 28, 1980 in Daegu, Korea. Raised in Masan, Pusan, Daejeon, he received the B.Sc. degree in civil and environmental engineering in 2009, the M.Sc. degree in environmental engineering from Woosong University, in Daejeon, Korea, in 2011.

He has worked as a researcher at Environmental Engineering Research Division of Water Resources \& Environmental Research Department in Korea Institute of Construction Technology from 2011. He has developed multi-purpose small-scale water treatment package system with the support of the Korean Ministry of Environment as a part of "Global Top Technology Development Project”. 